\title{
Genetics and Genomics of Pediatric Pulmonary Arterial Hypertension
}

\author{
Carrie L. Welch ${ }^{1}$ and Wendy K. Chung $1,2, * \mathbb{C}$ \\ 1 Department of Pediatrics, Columbia University Irving Medical Center, 1150 St. Nicholas Avenue, \\ New York, NY 10032, USA; cbw13@columbia.edu \\ 2 Department of Medicine, Columbia University Irving Medical Center, 622 W 168th St, \\ New York, NY 10032, USA \\ * Correspondence: wkc15@columbia.edu; Tel.: +212-851-5313
}

Received: 2 September 2020; Accepted: 13 October 2020; Published: 16 October 2020

\begin{abstract}
Pulmonary arterial hypertension (PAH) is a rare disease with high mortality despite recent therapeutic advances. The disease is caused by both genetic and environmental factors and likely gene-environment interactions. While PAH can manifest across the lifespan, pediatric-onset disease is particularly challenging because it is frequently associated with a more severe clinical course and comorbidities including lung/heart developmental anomalies. In light of these differences, it is perhaps not surprising that emerging data from genetic studies of pediatric-onset PAH indicate that the genetic basis is different than that of adults. There is a greater genetic burden in children, with rare genetic factors contributing to $\sim 42 \%$ of pediatric-onset PAH compared to $~ 12.5 \%$ of adult-onset $\mathrm{PAH}$. De novo variants are frequently associated with PAH in children and contribute to at least $15 \%$ of all pediatric cases. The standard of medical care for pediatric PAH patients is based on extrapolations from adult data. However, increased etiologic heterogeneity, poorer prognosis, and increased genetic burden for pediatric-onset PAH calls for a dedicated pediatric research agenda to improve molecular diagnosis and clinical management. A genomics-first approach will improve the understanding of pediatric PAH and how it is related to other rare pediatric genetic disorders.
\end{abstract}

Keywords: genomics; pediatrics; lung disease; pulmonary arterial hypertension

\section{Introduction}

Pulmonary arterial hypertension (PAH) is a rare disease with an estimated prevalence of 4.8-8.1 cases/million for pediatric-onset [1] and 15-50 cases/million for adult-onset disease [2]. Pathogenic changes in the pulmonary vasculature-including endothelial dysfunction, aberrant cell proliferation, and vasoconstriction-give rise to the clinical consequences of increased pulmonary vascular pressures, increased vascular resistance, heart failure, and premature death [3]. The disease is caused by genetic, epigenetic, and environmental factors, as well as gene-environment interactions wherein genetic contributions to disease risk are modified by environmental exposures. Causal genetic factors for PAH are typically autosomal dominantly inherited for genes such as BMPR2, the major gene causing familial forms of PAH (FPAH) [4,5]. Environmental risk factors include hypoxia and exposure to drugs and toxins [4]. Epigenetic factors include active histone mark H3K27ac [6]. Most of our understanding of PAH etiology and treatment is based upon studies in adults [7,8]. However, emerging clinical and genetic data indicate that there are fundamental differences between pediatricand adult-onset disease.

Pediatric PAH differs from the adult-onset disease in several important aspects, including sex bias, clinical presentation, etiology, and response to therapy [7-9]. The frequency of PAH is $\sim 3-4$-fold higher in females relative to males for adult-onset disease. However, data from the National Biological 
Sample and Data Repository for PAH (aka PAH Biobank, Table 1) [10,11] and other studies [12,13] indicate that the frequency of pediatric-onset PAH is similar for females and males, suggesting less dependence on sex-specific factors in children. Children present with increased severity of disease, e.g., elevated mean pulmonary artery pressure (mPAP), decreased cardiac output, and increased pulmonary vascular resistance, compared to adults at diagnosis (Table 1) $[10,11]$. The clinical manifestations likely reflect the complex etiology of disease in children. While prenatal and early postnatal influences on lung growth and development can contribute to the development of PAH across the lifespan, early developmental influences play a particularly prominent role in pediatric-onset PAH in which patients frequently have complex comorbidities such as congenital heart disease (APAH-CHD), Down syndrome, congenital diaphragmatic hernia $(\mathrm{CDH})$, and other developmental lung diseases, including persistent pulmonary hypertension of the newborn (PPHN) $[7,14,15]$. Histopathological studies have identified abnormal lung development and lung hypoplasia as common features of PAH, CHD, CDH, and Down syndrome [14,16]. While the mechanisms for impaired lung development are not known, altered expression of angiogenic and anti-angiogenic genes likely contribute [17-20]. Decreased lung vascular and alveolar growth predispose one to vascular injury during susceptible periods of growth and adaptation. The presentation of pediatric PAH with developmental comorbidities contributes to poor outcomes in these children $[7,15]$. Few pharmaceutical therapies are approved for use in children due to the lack of safety and efficacy data [8]. However, a retrospective study of pediatric PAH patients suggested that PAH patients with Down syndrome may be less responsive to PAH treatments than non-Down syndrome patients [21]. Clearly, pediatric-focused studies are needed to increase our understanding about the natural history, the pathogenic mechanisms, and the treatment of PAH in children. 
Table 1. Clinical characteristics and hemodynamic parameters of child- vs. adult-onset pulmonary arterial hypertension (PAH) cases at diagnosis. Data are from the PAH Biobank $(n=2572)$. Child-onset, $<18$ years of age at diagnosis. Mean \pm SD.

\begin{tabular}{|c|c|c|c|c|c|c|c|}
\hline Group (n) & Age at $d x(y)$ & F:M Ratio & mPAP (mm Hg) & mPCWP (mm Hg) & CO Fisk (L/min) & $\begin{array}{l}\text { PVR (Woods } \\
\text { Units) }\end{array}$ & Common Comorbidities \\
\hline Child (226) & $7.7 \pm 5.4$ & $1.65: 1$ & $55.1 \pm 18.6$ & $9.0 \pm 3.0$ & $3.2 \pm 1.6$ & $18.1 \pm 11.7$ & $\begin{array}{l}\mathrm{CHD}, \mathrm{CDH}, \mathrm{DS} \text {, lung } \\
\text { growth/development }\end{array}$ \\
\hline$p$-value & $<0.0001^{*}$ & $<0.0001^{* *}$ & $<0.0001^{*}$ & $<0.0001 *$ & $<0.0001 *$ & $<0.0001^{*}$ & \\
\hline
\end{tabular}

Abbreviations: $\mathrm{dx}$, diagnosis; F:M, female:male; mPAP, mean pulmonary artery pressure; mCWP, mean pulmonary capillary wedge pressure; $\mathrm{CO}$, cardiac output; $\mathrm{PVR}$, pulmonary vascular resistance; $\mathrm{CHD}$, congenital heart disease; $\mathrm{CDH}$, congenital diaphragmatic hernia; DS, Down syndrome; HTN, systemic hypertension. * Student's t-test, 2 -tailed. ${ }^{* *}$ Fisher exact test. 


\section{Genetics of Pediatric PAH-Current Knowledge}

Emerging data from genetic studies of pediatric-onset PAH indicate that the genetic basis in children is different from that of adults $[10,11,13]$. There is a greater genetic burden in children, with rare genetic factors contributing to $\sim 42 \%$ of pediatric-onset PAH compared to $\sim 12.5 \%$ of adult-onset PAH (Figure 1). De novo variants are frequent in children, likely contributing to $\sim 15 \%$ of pediatric PAH $[10,13]$. Among rare inherited variants, variants in BMPR2 are causal in $\sim 6.5-7 \%$ of both pediatricand adult-onset PAH; most of the cases are FPAH or idiopathic PAH (IPAH), rarely PAH associated with other diseases (APAH) [11,22], and no occurrences in PPHN have been reported to date [23]. Notably, two of the other known causal genes with the highest frequencies of rare deleterious variants among pediatric cases-TBX4 and SOX17-are highly expressed in embryonic tissues and have prominent roles in lung and vasculature development [24-26]. The mean age of PAH onset by risk gene is shown for twelve of the genes in Figure 2.

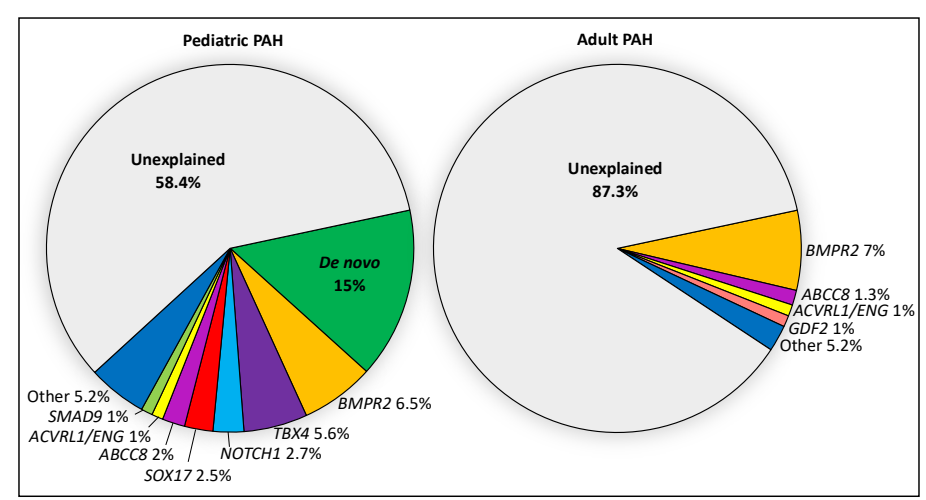

Figure 1. Relative contributions of de novo mutations and $18 \mathrm{PAH}$ risk genes in a cohort of 443 pediatric and 2628 adult cases from CUIMC and the PAH Biobank. Risk genes include BMPR2, ABCC8, ACVRL1, ATP13A3, BMPR1B, CAV1, EIF2AK4, ENG, GDF2, KCNA5, KCNK3, KDR, NOTCH1, SMAD1, SMAD4, $S M A D 9$, and TBX4. PAH cases include IPAH, APAH, FPAH and other rarer cases.

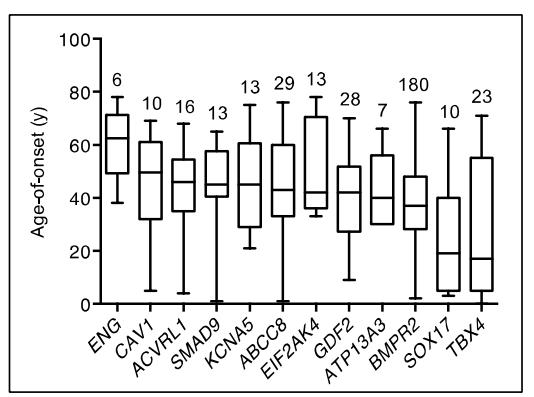

Figure 2. Age-of-disease onset for all PAH Biobank cases with rare deleterious variants in known PAH risk genes. Box plots showing median, interquartile range and $\mathrm{min} / \mathrm{max}$ values for age-of-disease onset (i.e., age at diagnostic right heart catheterization). The number of cases carrying variants for each gene is given above each box plot. Genes represented by less than four cases are not shown.

\subsection{TBX4}

Unlike BMPR2 and other known causal PAH genes, TBX4 is not expressed in pulmonary arterial endothelial cells or smooth muscle cells. TBX4 is a transcription factor in the T-box gene family that is co-expressed with TBX5 throughout the mesenchyme of developing lung and trachea [24]. Lung-specific $T b \times 4 / T b x 5$ deficient mice exhibit impaired lung branching and hypoplasia during gestation as well as early postnatal death due to severe respiratory disease [24]. TBX4 is also expressed in the developing atrium of the heart and the limb buds [27]. In humans, rare but recurrent microdeletions of chromosome 17q23, including TBX4, have been observed in children with complex phenotypes including PAH, heart and skeletal defects, and neurodevelopmental delay [28-30]. More recently, TBX4-specific likely 
gene-disrupting (LGD) and damaging missense variants have been associated with PAH with or without small patella syndrome (OMIM \#147891), most frequently in pediatric cases [11,13,22,31,32]. In two independent cohorts [11,13], rare deleterious variants in TBX4 showed significant enrichment among pediatric- compared to adult-onset IPAH cases (Columbia University Irving Medical Center, CUIMC, cohort: $10 / 130$ vs. 0/178; PAH Biobank: $12 / 155$ vs. 1/257, respectively). In the PAH Biobank, ten additional TBX4 variants were identified for other PAH subtypes, including three APAH-CHD cases with heart defects. In a cohort of 256 APAH-CHD cases (144 pediatric- and 112 adult-onset), we identified TBX4 variants in seven cases with age-of-onset from newborn to 11 years, one associated with alveolar hypoplasia [22]. Together, the data suggest that rare TBX4 variants contribute to $7.7 \%$ of pediatric IPAH and $4.9 \%$ of pediatric APAH-CHD cases. Notably, TBX4 variants have not been observed in CHD alone [33].

Skeletal and other developmental defects are not routinely assessed as part of a PAH diagnosis and, as such, some dual diagnoses may have been missed for PAH cases. To this end, Galambos et al. [34] carried out detailed clinical and histopathologic characterization of 19 pediatric PAH cases with TBX4 variants: 6 microdeletions, 12 LGD, and 1 missense. Seven infants had evidence of abnormal distal lung development, and there was a high frequency of heart and skeletal developmental anomalies; neurodevelopmental delay was also observed among those patients with microdeletions, likely due to haploinsufficiency of other adjacent genes. Ten newborns presented with PPHN which resolved but recurred later in infancy or childhood [34]. A report from the National French Registry [35] concurred these findings of skeletal, heart, and lung developmental anomalies in PAH cases. Why some patients present with PAH alone, small patella syndrome alone, PAH with small patella syndrome, or PAH with other developmental defects is not understood at this time but may depend on the variant type or the protein location of gene variants, other genetic or epigenetic factors, or other environmental factors affecting the specific transcriptional pathways regulated by TBX4. It is clear that genetic diagnosis of a rare deleterious TBX4 variant or TBX4-containing microdeletion in pediatric PAH predicts a more complex developmental phenotype (TBX4 syndrome [36]). Chest imaging for severe and diffuse features of pulmonary growth arrest, assessment for congenital heart defects, physical examination of hands and feet, and radiological assessment of pelvic areas are recommended. In addition, a TBX4 diagnosis predicts potential recurrence of PAH following neonatal PPHN suggesting that annual screening by echocardiography may be useful.

\section{2. $S O X 17$}

SOX17 is a member of the conserved family of SRY-related HMG box transcription factors, originally identified as key regulators of male sex determination but now recognized to have critical roles in embryogenesis $[25,26]$. SOX17 is specifically required for endoderm formation and vascular morphogenesis [25,37,38], and germline deletion of Sox17 results in embryonic lethality by E10.5 [25]. In the developing murine lung, Sox17 is expressed in mesenchymal progenitor cells and is then restricted to endothelial cells of the pulmonary vasculature [39]. Conditional deletion of Sox17 in mesenchymal progenitor cells causes abnormal pulmonary vascular morphogenesis, resulting in postnatal cardiopulmonary dysfunction and juvenile death [39]. Endothelial-specific inactivation of Sox17 in mice leads to impaired arterial specification and embryonic death or, with conditional postnatal inactivation, arterial-venous malformations [37]. Transcriptional activation of Sox17 via hypoxia-induced factor $1 \alpha$ leads to upregulation of cyclin-E1 and endothelial regeneration in response to lung injury [40]. We identified SOX17 as a candidate risk gene for PAH using exome sequencing data in a cohort of 256 APAH-CHD patients [22]. Thirteen cases with rare predicted deleterious SOX17 variants were identified, seven LGD and six missense variants located primarily within the conserved HMG box domain (Figure 2). Fifty-six percent of the overall cohort were pediatric cases, but nine of thirteen cases with rare deleterious variants in SOX17 were pediatric cases with mean age-of-onset of 14 years. A recurrent frameshift variant, p.(Leu167Trpfs*213), was identified in three APAH-CHD cases with age-of-onset ranging from 7 months to 5 years. We $[11,22]$ and others $[41,42]$ 
have identified SOX17 variants in IPAH cases but with lower frequency in adults. Combined data from five cohorts $([11,13,22,41,42]$ indicate that SOX17 variants contribute to $7 \%$ of all pediatric-onset PAH cases compared to $0.4 \%$ of adult-onset cases (Figure 3). Protein modeling indicates that at least three of the APAH-CHD case missense variants localize to the transcription factor DNA binding pocket [22], and missense variants in this region have been shown to impair both direct DNA binding and SOX17/ $\beta$-catenin nucleoprotein complexes at target gene promoters $[43,44]$. These data suggest that haploinsufficiency with complete or partial loss of function alleles is the likely mechanism of SOX17 risk in PAH.

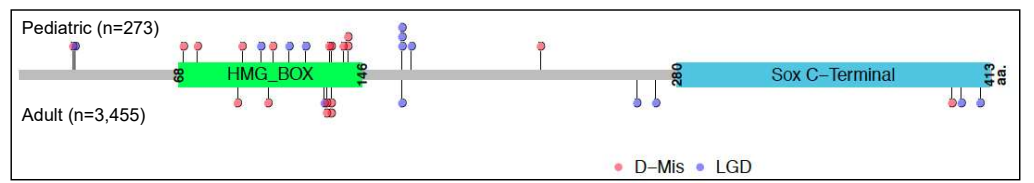

Figure 3. Locations of SOX17 likely gene disrupting (LGD) and rare predicted deleterious missense (D-Mis) variants carried by PAH cases from five cohorts from the US, UK and Japan. Variants carried by pediatric cases $(n=19)$ are shown above the protein schematic and variants carried by adult cases $(n=13)$ below the schematic. The combined datasets include 273 pediatric and 3455 adult cases $[11,13,22,41,42]$.

Some variants in SOX17 downstream target genes may be predicted to mimic the consequences of SOX17 LGD variants or haploinsufficiency. We identified 163 rare predicted deleterious variants in 149 putative SOX17 target genes, most with prominent expression in pulmonary artery endothelial cells and/or developing heart [22]. For the 32 LGD and the 131 missense variants, we observed a moderate but significant enrichment of rare missense variants in cases compared to controls. Approximately one-third of these genes had top quartile gene expression in both pulmonary artery endothelial cells and developing heart. Pathway analysis indicated that the genes have likely roles in developmental biology, small molecule transport/homeostasis, and extracellular matrix interactions (Table 2). While these results are intriguing, they require confirmation in larger cohorts to determine which specific SOX17-regulated genes/pathways contribute to PAH risk.

Table 2. Biological pathway analysis of SOX17 target genes harboring PAH-CHD patient rare deleterious variants. Data obtained using Reactome 2016. Pathways with false discovery rate (FDR)-adjusted $p$-value $\leq 0.05$ are listed.

\begin{tabular}{|c|c|c|c|c|c|}
\hline Term & $\begin{array}{l}\text { Reactome } \\
\text { ID }\end{array}$ & $\begin{array}{l}\text { \# Genes in } \\
\text { Overlap }\end{array}$ & $p$-Value & $\begin{array}{l}\text { Adjusted } \\
p \text {-Value }\end{array}$ & Genes \\
\hline $\begin{array}{l}\text { Developmental } \\
\text { biology }\end{array}$ & $\begin{array}{l}\text { R-HAS- } \\
1266738\end{array}$ & $16 / 786$ & $6.8 \times 10^{-5}$ & 0.03 & $\begin{array}{c}\text { KLB, ROBO2, LAMA1, } \\
\text { EGF, ANK3, LAMC, } \\
\text { SLC2A4, MED6, SPRED2, } \\
\text { MEIS1, NRFA2, PCMC4, } \\
\text { NF1, EP300, TCF4, } \\
\text { EPHB4 }\end{array}$ \\
\hline $\begin{array}{l}\text { Transmembrane } \\
\text { transport of small } \\
\text { molecules }\end{array}$ & $\begin{array}{l}\text { R-HAS- } \\
382561\end{array}$ & $13 / 594$ & $1.7 \times 10^{-4}$ & 0.03 & $\begin{array}{c}\text { RYR2, ABCC4, ABCC1, } \\
\text { SLC1A3, SL\#3A4, } \\
\text { SLC8A1, CLCN5, SLCA9, } \\
\text { ATPB7, ASPH, WNK1, } \\
\text { NUP35, EMB }\end{array}$ \\
\hline $\begin{array}{l}\text { Non-integrin } \\
\text { membrane } \\
\text { extracellular matrix } \\
\text { interactions }\end{array}$ & $\begin{array}{l}\text { R-HAS- } \\
3000171\end{array}$ & $4 / 42$ & $1.7 \times 10^{-4}$ & 0.03 & $\begin{array}{c}\text { LAMA1, LAMA4, } \\
\text { LAMC1, THBS1 }\end{array}$ \\
\hline Ion homeostasis & $\begin{array}{l}\text { R-HAS- } \\
5578775\end{array}$ & $4 / 51$ & $1.7 \times 10^{-4}$ & 0.03 & $\begin{array}{c}R Y R 2, A S P H, T P R 3, \\
S L C 8 A 1\end{array}$ \\
\hline
\end{tabular}




\subsection{The Relative Contribution of Other Known PAH Risk Genes}

Among the combined CUIMC and PAH Biobank pediatric cohort of 443 non-overlapping cases, rare deleterious variants in other known PAH risk genes altogether account for $\sim 12 \%$ of cases (27 IPAH, 26 APAH-CHD, 2 APAH-HHT). Variants in NOTCH1 account for $2.7 \%$ of pediatric PAH cases (2 IPAH, 10 APAH-CHD). NOTCH1 encodes a transmembrane receptor that facilitates intercellular interactions and signaling with known roles in development and is a known CHD risk gene. Variants in $A B C C 8$ and SMAD9 account for $2 \%$ and $1 \%$ of cases, respectively, including both IPAH and APAH-CHD. Variants in ACVRL1/ENG account for 1\% of cases, including two APAH-HHT cases. BMPR1B, CAV1, GDF2, KCNK3 and KDR/BMP9 were identified in one to four cases each, accounting for $<1 \%$ for each gene. In addition to autosomal dominant inheritance, recessively inherited EIF2AK4 variants have been identified in 1-3\% of children in European and Chinese cohorts $[31,45,46]$. In addition, a rare occurrence of recessively inherited GDF2 variants has been reported for a 3-year-old boy with right heart failure [47]. Autosomal recessive inheritance of other risk variants may cause very early-onset severe $\mathrm{PAH}$, and additional pediatric studies are necessary to evaluate rare recessive genetic etiologies.

\subsection{De Novo Variants}

De novo variants have emerged as an important class of genetic factors underlying rare diseases, especially early-onset severe conditions $[15,33,48-50]$, due to strong negative selection decreasing reproductive fitness [51]. We recently assessed the role of rare deleterious de novo variants in pediatric PAH using a cohort of 124 parent-child trios (56\% IPAH, 38\% APAH-CHD, $6 \%$ other PAH) [10]. We observed a 2.5-fold enrichment of de novo variants among all PAH cases compared to the expected rate, almost entirely due to genes that are highly expressed in developing lung or heart (Table 3). Among the PAH cases identified with de novo variants, $54 \%$ were IPAH, $32 \%$ were APAH-CHD, and $14 \%$ other PAH; at least $20 \%$ of the de novo variant carriers had additional diagnoses of other congenital anomalies. De novo variants were identified in three known PAH risk genes (four variants in TBX4, two in BMPR2, one in ACVRL1) and 23 additional genes with high expression in developing lung and/or heart but little to no previous association with PAH. Based on the enrichment rate, we estimate that $\sim 18$ of the identified variants are likely to be implicated in pediatric PAH. The identified genes fit a general pattern for developmental disorders-genes intolerant to LGD variants ( $p L I>0.5$ for $40 \%$ of the PAH genes) and with known functions important for coordinated organogenesis, including transcription factors, RNA binding proteins, protein kinases, and chromatin modification. Three of the genes are known CHD risk genes (NOTCH1, PTPN11, and RAF1). NOTCH1 is the most commonly associated gene for the congenital heart defect of tetralogy of Fallot, [52] and the NOTCH1 de novo variant carrier had a diagnosis of APAH-CHD with tetralogy of Fallot. Rare variants in PTPN11 and RAF1 are causal for Noonan syndrome, which has a high frequency of congenital heart defects. The de novo variants identified in both of these genes are known causal Noonan syndrome variants [53], and three cases of fatal pediatric PAH with Noonan syndrome have been previously reported [54,55]. We previously reported rare inherited variants in NOTCH1 $(n=5)$, PTPN11 $(n=1)$, and RAF1 $(n=2)$ carried by APAH-CHD cases [22]. Aside from known PAH and CHD genes, at least eight of the other genes with identified de novo variants have known or plausible roles in lung/vascular development (Table 4). For example, AMOT (angiomotin) encodes an angiostatin-binding protein involved in embryonic endothelial cell migration and tube formation as well as endothelial cell tight junctions and angiogenesis [56-58]. HSPA4 (heat shock protein A4) encodes a chaperone that, together with HSPA4L, functions in embryonic lung maturation and dual deletion of Hspa4/Hspa4l, which results in intrauterine pulmonary hypoplasia and early neonatal death [59]. KEAP1 (Kelch-like ECH associated protein 1) regulates oxidative stress and apoptosis through interactions with NRF2 in murine vascular cells [60], and endothelial-specific deletion of NRF2 reduces endothelial sprouting in vivo [61] and increases susceptibility to bronchopulmonary dysplasia and other respiratory diseases [62]. An NRF2 activator is currently being investigated in a phase 2 clinical trial for PAH (ichgcp.net/clinical-trials-registry/NCT02036970). Finally, one third of all of the de 
novo variants identified in the trio analysis are in causal genes for developmental syndromes, consistent with the enrichment of developmental phenotypes among the variant carriers [10]. The genes identified in this study require replication in a larger pediatric cohort. In addition, genes with rare variants can be entered into GeneMatcher to identify other cases with rare variants in the same gene and compare genotypes and phenotypes. Due to the low background rate of rare deleterious de novo variants [63], the statistical evidence for a candidate risk gene is effectively equivalent to multiplicity. That is, genes with $\geq 2$ rare deleterious de novo variants are unlikely to be mutated by chance and should be considered candidate risk genes. The genes and the variants identified in the pediatric trio analysis have not been observed in adult-onset cases and likely will be specific to pediatric PAH. Thus, it is imperative that larger pediatric-focused PAH cohorts are studied to advance our knowledge of the causal genes specific to pediatric-onset PAH.

Table 3. Burden of de novo variants in 5756 genes highly expressed in developing lung (murine E16.5 lung stromal cells) and/or developing heart (murine E14.5 heart) in pediatric-onset PAH ( $n=124$ child/parent trios).

\begin{tabular}{cccccc}
\hline Variant Type * $^{*}$ & $\begin{array}{c}\text { Observed in } \\
\text { Trios }(\boldsymbol{n = 1 2 4 )})\end{array}$ & $\begin{array}{c}\text { Expected by } \\
\text { Chance }\end{array}$ & Enrichment & $\boldsymbol{p}$-Value & $\begin{array}{c}\text { Estimated \# of } \\
\text { True Risk Variants }\end{array}$ \\
\hline SYN & 18 & 14.0 & 1.3 & 0.28 & - \\
LGD & 11 & 4.7 & 2.4 & 0.06 & - \\
MIS & 40 & 31.7 & 1.3 & 0.15 & - \\
D-MIS & 19 & 7.2 & 2.6 & $2.0 \times 10^{-4}$ & 12 \\
LGD + D-MIS & 30 & 11.8 & 2.5 & $7.0 \times 10^{-6}$ & 18 \\
\hline
\end{tabular}

* SYN, synonymous; LGD, likely gene disrupting; MIS, missense; D-MIS, predicted deleterious missense based on REVEL score $>0.5$.

Table 4. Novel genes with rare deleterious de novo variants in pediatric-onset PAH ( $n=124$ trios).

\begin{tabular}{|c|c|c|c|c|c|c|c|c|}
\hline $\begin{array}{c}\text { Gene } \\
\text { Symbol }\end{array}$ & $\begin{array}{l}\text { Variant } \\
\text { Type }\end{array}$ & Protein Change & $\begin{array}{l}\text { REVEL } \\
\text { Score }\end{array}$ & $\begin{array}{l}\text { CADD } \\
\text { Score }\end{array}$ & $\begin{array}{c}\text { Allele } \\
\text { Frequency } \\
\text { (gnomAD) }\end{array}$ & $\begin{array}{c}\text { E16.5 Lung } \\
\text { Expression } \\
\text { Rank }\end{array}$ & $\begin{array}{c}\text { E14.5 } \\
\text { Heart } \\
\text { Expression } \\
\text { Rank }\end{array}$ & $\begin{array}{c}\text { Variant } \\
\text { Carrier } \\
\text { PAH } \\
\text { Subtype }\end{array}$ \\
\hline AMOT & LGD & p.(Leu320Cysfs*55) & & 31 & & 68 & 95 & IPAH \\
\hline CSNK2A2 & D-MIS & p.(His184Leu) & 0.50 & 25 & & 55 & 77 & IPAH \\
\hline HNRNPF & LGD & p.(Tyr210Leufs*14) & . & 29 & & 85 & 98 & $\begin{array}{c}\text { PPHN, } \\
\text { PAH }\end{array}$ \\
\hline HSPA4 & D-MIS & p.(pro684Arg) & 0.62 & 30 & $4.1 \times 10^{-6}$ & 43 & 96 & PAH-CHD \\
\hline KDM3B & D-MIS & p.(Pro1100Ser) & 0.66 & 29 & & 89 & 87 & $\begin{array}{l}\text { IPAH } \\
\text { IPAH }\end{array}$ \\
\hline KEAP1 & LGD & p.(Tyr584*) & . & 35 & & 79 & 82 & $\begin{array}{c}\text { with dev } \\
\text { delay }\end{array}$ \\
\hline MECOM & D-MIS & p.(Phe762Ser) & 0.76 & 32 & & 82 & 60 & $\begin{array}{l}\text { IPAH } \\
\text { IPAH }\end{array}$ \\
\hline ZMYM2 & LGD & p.(Arg540*) & . & 36 & & 93 & 77 & $\begin{array}{c}\text { with } \\
\text { skeletal } \\
\text { anomalies }\end{array}$ \\
\hline
\end{tabular}

$A M O T$, angiomotin; CSKN2A2, casein kinase II, $\alpha 2$; HNRNPF, heterogeneous nuclear ribonucleoprotein F; HSPA4, heat shock protein A (HSP70), member 4; KDM3B, lysine demethylase 3B; KEAP1, Kelch-like ECH-associated protein 1; MECOM, MDS1 and EVI1 complex locus; ZMYM2, zinc finger protein 620. LGD, likely gene disrupting; MIS, missense; D-MIS, predicted deleterious missense based on REVEL score $>0.5$. Allele frequency "." absent from gnomAD.

\subsection{Genetic Ancestry}

Most of the large genetic studies conducted to date have utilized cohorts of predominantly European ancestry. However, the role of specific genes in PAH may be heterogeneous across genetic ancestries, and the results of these studies may not be generalizable to all other populations. For example, the frequency of $A C V R L 1$ and ENG variants combined is $\sim 1 \%$ among pediatric IPAH cases of European ancestry [11,13], but the frequency of ACVRL1 alone may be closer to $13 \%$ among Asian children [64]. 
GDF2/BMP9 was recently identified as a novel PAH risk gene with genome-wide significance in both European [41] and Asian [65] cohorts with replication in the PAH Biobank cohort [11]. Similar to other PAH risk genes, the mode of inheritance was autosomal dominant. The frequency of GDF2/BMP9 variants among children was 2.1\% (2/94 cases) in the PAH Biobank and 5.2\% (3/57 cases) in the Asian cohort, suggesting that GDF2/BMP9 variants might be a more frequent cause of PAH among Asian children. Further study is required to determine whether this difference is a true genetic ancestry effect or random variation due to relatively small sample size or differences in bioinformatic pipelines. A PAH case study of a five-year-old boy of Hispanic ancestry identified a homozygous GDF2/BMP9 LGD variant, NM_016204.1:c.76C > T; p.(Gln26Ter) [47]. The unaffected parents were heterozygous for the variant. Interestingly, the gnomAD population database (gnomADv2.1.1, $n=141,456$ samples) [66] contains only two heterozygous counts of this allele, both of Latino ancestry, suggesting that this might be an ancestry-specific allele. Clearly, larger studies of children with greater diversity are needed to define population-specific risk gene allele frequencies as well as ancestral-specific genetic factors.

\subsection{The Role of Other "Omics" in PAH}

In addition to DNA sequencing to identify genetic etiologies of PAH, other "omics", including RNA sequencing, metabolomics, and proteomics, can provide valuable predictions of who is at risk for disease, define endophenotypes, and guide effective therapies [67,68]. For example, West and colleagues performed RNA sequencing of blood lymphocytes derived from BMPR2 variant carriers with and without PAH to identify transcriptional patterns relevant to disease penetrance [69]. More recently, FHIT was identified as a potentially clinically relevant BMPR2 modifier gene through an siRNA screen of BMPR2 signaling regulatory genes combined with publicly available PAH RNA expression data. Subsequently, the authors showed that pharmaceutical upregulation of FHIT prevented and reversed experimental pulmonary hypertension in a rat model [70]. Rhodes and colleagues utilized metabolomics to identify circulating metabolites that distinguish PAH cases from healthy controls, to predict outcomes among PAH cases, and to monitor metabolite levels over time to determine whether correction could affect outcomes [71]. Stearman et al. combined gene expression data with pathway analyses to identify a transcriptional framework for PAH-affected lungs [72]. Similarly, Hemnes and colleagues used transcriptomics to identify RNA expression patterns predictive of vasodilator responsiveness among PAH patients [73]. These studies highlight the promise of other omics in predictions of PAH risk, diagnosis, classification, drug responsiveness, and prognosis. However, such studies have not been conducted in children. Detailed omic phenotyping requires biologic sampling, which can be difficult in pediatric patients, especially for the very young or those with complex medical conditions. We propose a pilot genomics-first approach followed by detailed phenotyping of patients grouped by genetic diagnosis to enrich the biologic sampling and assess utility before performing larger studies across all pediatric PAH patients.

\section{A Genomics First Approach towards Better Understanding of Pediatric PAH}

Identification of molecular subtypes of PAH has been proposed as a means to improve risk stratification, treatment, and outcomes. Obtaining a genetic diagnosis in children requires more extensive genetic testing than in adults (Figure 4). If testing for a panel of genes known to be associated with PAH is not diagnostic, children should be evaluated genome-wide for rare de novo and inherited variants with trio (parental and child) exome sequencing/chromosome microarray or genome sequencing. With knowledge of the causal gene, natural history, penetrance, and response to treatment can be refined for that specific genetic subtype of PAH to allow for more precise care for each genetically defined group. Individuals across genes in the same biological pathway can then be compared to assess similarities and differences. 


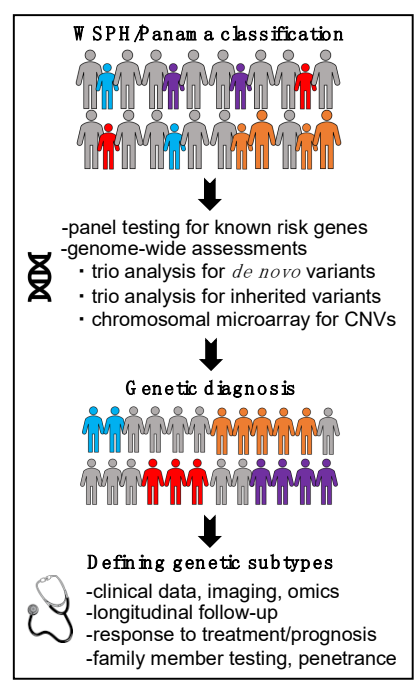

Figure 4. Genomic approach to improve understanding of pediatric PAH.

Collaboration across national and international clinical PH sites will be necessary to yield sufficient sample sizes due to the extremely small number of pediatric $\mathrm{PAH}$ patients at single $\mathrm{PH}$ sites, heterogeneity of risk genes for PAH, and need for ancestral diversity. PPHNet is an example of a pediatric-specific PAH consortium with ongoing recruitment across 13 North American clinical sites [74-78]. PVDomics [79], a US multicenter study launched in 2014, and PAH-ICON (pahicon.com), a new international effort, represent additional large-scale PAH cohorts. PAH was defined as mPAP $\geq 25 \mathrm{mmHg}$ but was recently updated to include mPAP $20-25 \mathrm{mmHg}$ in both children and adults [8]. Due to variability in pulmonary hemodynamics during the post-natal transition period, pediatric PAH is defined by elevated mPAP after 3 months of age in combination with pulmonary vascular resistance as indexed to body surface area, PVRI $\geq 3$ Woods units $/ \mathrm{m}^{2}$ [8]. Clinical classification of PAH subtypes aims to improve clinical management and enhance research efforts and is typically based on the World Symposium on Pulmonary Hypertension (WSPH) system, updated during the 2018 Nice session [80]. In children, use of a pediatric-specific classification system developed in Panama by the Pulmonary Vascular Research Institute (PVRI) Pediatric Task Force [81] provides more definitive classification of developmental and complex phenotypes.

Biological trios composed of two unaffected parents and an affected child are preferred over singleton cases for pediatric studies of PAH in order to identify both inherited and de novo variants causal for disease. However, as the number of ethnically matched genomic data in public databases increases, the need for trios will decrease. DNA can be reliably obtained from small samples of blood or saliva. We have developed methods in a large national autism study to collect saliva from pediatric patients and their parents in their homes, with instructional videos to support clinical sites with remote biospecimen collection $[82,83]$. Biological samples can be shipped to a central biorepository for DNA extraction and then processed and sequenced using a single genetic platform. Since annotation tools for predicting relative pathogenicity of noncoding variants are still under development, and because the incremental yield of structural variants identified from genome sequencing is low, there is currently little added value in analysis of genome sequencing compared to exome sequencing data. Following extensive quality control, filtering, and annotation, sequencing data are screened for rare deleterious variants in known candidate genes or undergo trio analysis for de novo variants or association analysis for inherited variants $[10,11]$. Candidate genes identified by these methods are further assessed by mapping the locations of variants to protein structures, assessing expression in PAH-relevant tissues and cell types, assessing variant function in vitro, and assessing the impact of pathogenic variants in vivo in model organisms. Human mutations can be introduced into cells and PAH-sensitized mice using CRISPR technology. Phenotypic "rescue" by exogenous delivery of normal proteins can add evidence to support causation. 
Once genetic subtypes are defined, demographic data, clinical phenotypes, and imaging data (pulmonary vascular angiography, chest X-ray or CT scans, chest/cardiac MRI, and lung biopsies) can be compared among cases with variants in the same gene/pathway. Relevant cases can be recalled or remotely interviewed for targeted clinical assessments to determine if there are similarities among cases with rare variants in the same gene/pathway.

To increase rigor and assess the full phenotypic spectrum of the new genetic subtypes, additional cases can be identified using GeneMatcher, clinical diagnostic laboratories, and large sequencing centers. Longitudinal phenotypes of the genetic subtypes can be assessed retrospectively and prospectively, including death/transplant, response to medication, other medical diagnoses, and changes in lung function. For inherited variants, cascade genetic testing of family members with clinical evaluation of "unaffected" individuals who carry the relevant genetic variant can inform penetrance by age and sex. To support families with genetic diagnoses, "virtual" family meetings can be organized to update families on new findings related to their conditions and build communities for each of the rare endophenotypes.

The value of a genetic diagnosis to families is three-fold: (1) identification of other associated features, (2) identification of family members at risk for developing $\mathrm{PAH}$, and (3) clarification of reproductive risks and provide family planning options. Biallelic mutations in EIF2AK4 are diagnostic for pulmonary veno-occlusive disease/pulmonary capillary hemangiomatosis [84], which can be difficult to diagnose clinically without a lung biopsy, and patients can be listed for transplant earlier in the course of disease, which may improve outcomes. As mentioned, TBX4 variant carriers should be assessed for associated developmental (lung, heart) and orthopedic (hips, knees, feet) issues. $E N G / A C V R L 1$ variant carriers are prone to arteriovenous malformations in brain, intestine, lung, and liver [85]; these patients require periodic MRI surveillance. After making a genetic diagnosis in a PAH patient, additional family members can be screened for the family variant to identify those at risk who may benefit from annual surveillance and early diagnosis/treatment. Furthermore, diagnosed young adults can make informed decisions regarding family planning.

\section{Conclusions}

Pediatric PAH differs from adult-onset PAH in many important aspects, including clinical presentation, etiology, genetic burden, and specific genes involved. In many young children, PAH is a developmental disease with a complex phenotype. TBX4 and SOX17 are examples of developmental genes in which rare deleterious variants occur much more frequently in pediatriccompared to adult-onset PAH. De novo variants likely contribute to at least $15 \%$ of pediatric-onset $\mathrm{PAH}$, but the specific genes require confirmation in larger pediatric cohorts. Many genes with de novo variants likely contribute to developmental phenotypes and complex medical conditions. A genomics-first approach to pediatric PAH starts with a genetic diagnosis followed by phenotypic characterization of cases with variants in the same genes/pathways. Large, diverse pediatric populations are needed to confirm the candidate genes identified thus far, identify new genes, characterize each rare endophenotype and natural history, and assess the efficacy of therapies to inform more precise clinical management. In addition, questions related to which children are at risk for developing $\mathrm{PAH}$ - especially children with $\mathrm{CHD}, \mathrm{CDH}$, bronchopulmonary dysplasia, and Down syndrome-may be answered. The yield of genetic diagnoses in pediatric-onset PAH cohorts is significantly greater than the yield in adult-onset cohorts. However, identification of genes, pathways, and networks in children could provide novel targets for therapy not only for children but for all patients with and at high risk for PAH.

Author Contributions: Writing—original draft preparation, C.L.W.; writing-review and editing, W.K.C.; funding acquisition, W.K.C. All authors have read and agreed to the published version of the manuscript.

Funding: This research was funded by NIH U01HL125218 and the JPB Foundation (W.K.C.).

Acknowledgments: We are grateful to the patients who have contributed to these studies. 
Conflicts of Interest: The authors declare no conflict of interest.

\section{References}

1. Li, L.; Jick, S.S.; Breitenstein, S.; Hernandez, G.; Michel, A.; Vizcaya, D. Pulmonary arterial hypertension in the USA: An epidemiological study in a large insured pediatric population. Pulm. Circ. 2017, 7, 126-136. [CrossRef] [PubMed]

2. Humbert, M.; Sitbon, O.; Chaouat, A.; Bertocchi, M.; Habib, G.; Gressin, V.; Yaici, A.; Weitzenblum, E.; Cordier, J.F.; Chabot, F.; et al. Pulmonary arterial hypertension in France. Am. J. Respir. Crit. Care Med. 2006, 173, 1023-1030. [CrossRef]

3. Ryan, J.J.; Archer, S.L. The right ventricle in pulmonary arterial hypertension: Disorders of metabolism, angiogenesis and adrenergic signaling in right ventricular failure. Circ. Res. 2014, 115, 176-188. [CrossRef] [PubMed]

4. Morrell, N.W.; Aldred, M.A.; Chung, W.K.; Elliott, C.G.; Nichols, W.C.; Soubrier, F.; Trembath, R.C.; Loyd, J.E. Genetics and genomics of pulmonary arterial hypertension. Eur. Respir. J. 2019, 53, 1801899. [CrossRef] [PubMed]

5. Southgate, L.; Machado, R.D.; Gräf, S.; Morrell, N.W. Molecular genetic framework underlying pulmonary arterial hypertension. Nat. Rev. Cardiol. 2020, 17, 85-95. [CrossRef] [PubMed]

6. Reyes-Palomares, A.; Gu, M.; Grubert, F.; Berest, I.; Sa, S.; Kasowski, M.; Arnold, C.; Shuai, M.; Srivas, R.; Miao, S.; et al. Remodeling of active endothelial enhancers is associated with aberrant gene-regulatory networks in pulmonary arterial hypertension. Nat. Commun. 2020, 11, 1673. [CrossRef]

7. Hansmann, G. Pulmonary hypertension in infants, children, and young adults. J. Am. Coll. Cardiol. 2017, 69, 2551-2569. [CrossRef] [PubMed]

8. Rosenzweig, E.B.; Abman, S.H.; Adatia, I.; Beghetti, M.; Bonnet, D.; Haworth, S.; Ivy, D.D.; Berger, R.M. Paediatric pulmonary arterial hypertension: Updates on definition, classification, diagnostics and management. Eur. Respir. J. 2019, 53, 1801916. [CrossRef]

9. Saji, T. Update on pediatric pulmonary arterial hypertension. Differences and similarities to adult disease. Circ. J. 2013, 77, 2639-2650. [CrossRef]

10. Zhu, N.; Swietlik, E.M.; Welch, C.L.; Pauciulo, M.W.; Hagen, J.J.; Zhou, X.; Guo, Y.; Karten, J.; Pandya, D.; Tilly, T.; et al. Rare variant analysis of 4241 pulmonary arterial hypertension cases from an international consortium implicate FBLN2, PDGFD and rare de novo variants in PAH. bioRxiv 2020, 2029, 124255.

11. Zhu, N.; PAH Biobank Enrolling Centers' Investigators; Pauciulo, M.W.; Welch, C.L.; Lutz, K.A.; Coleman, A.W.; Gonzaga-Jauregui, C.; Wang, J.; Grimes, J.M.; Martin, L.J.; et al. Novel risk genes and mechanisms implicated by exome sequencing of 2572 individuals with pulmonary arterial hypertension. Genome Med. 2019, 11, 69. [CrossRef] [PubMed]

12. Barst, R.J.; McGoon, M.D.; Elliott, C.G.; Foreman, A.J.; Miller, D.P.; Ivy, D.D. Survival in childhood pulmonary arterial hypertension: Insights from the registry to evaluate early and long-term pulmonary arterial hypertension disease management. Circulation 2012, 125, 113-122. [CrossRef]

13. Zhu, N.; Gonzaga-Jauregui, C.; Welch, C.L.; Ma, L.; Qi, H.; King, A.K.; Krishnan, U.; Rosenzweig, E.B.; Ivy, D.D.; Austin, E.D.; et al. Exome sequencing in children with pulmonary arterial hypertension demonstrates differences compared with adults. Circ. Genom. Precis. Med. 2018, 11, e001887. [CrossRef] [PubMed]

14. Abman, S.H.; Baker, C.; Gien, J.; Mourani, P.; Galambos, C. The Robyn Barst memorial lecture: Differences between the fetal, newborn, and adult pulmonary circulations: Relevance for age-specific therapies (2013 grover conference series). Pulm. Circ. 2014, 4, 424-440. [CrossRef] [PubMed]

15. Qiao, L.; Wynn, J.; Yu, L.; Ms, R.H.; Zhou, X.; Duron, V.; Aspelund, G.; Farkouh-Karoleski, C.; Zygumunt, A.; Krishnan, U.S.; et al. Likely damaging de novo variants in congenital diaphragmatic hernia patients are associated with worse clinical outcomes. Genet. Med. 2020, 1-9. [CrossRef]

16. Bush, D.; Abman, S.H.; Galambos, C. Prominent intrapulmonary bronchopulmonary anastomoses and abnormal lung development in infants and children with down syndrome. J. Pediatr. 2017, 180, 156-162.e1. [CrossRef]

17. Sánchez, O.; Dominguez, C.; Ruiz, A.; Ribera, I.; Alijotas-Reig, J.; Roura, L.C.; Carreras, E.; Llurba, E. Angiogenic gene expression in down syndrome fetal hearts. Fetal Diagn. Ther. 2016, 40, 21-27. [CrossRef] 
18. Galambos, C.; Minic, A.D.; Bush, D.; Nguyen, D.; Dodson, B.; Seedorf, G.; Abman, S.H. Increased lung expression of anti-angiogenic factors in down syndrome: Potential role in abnormal lung vascular growth and the risk for pulmonary hypertension. PLoS ONE 2016, 11, e0159005. [CrossRef]

19. Reuter, M.S.; Jobling, R.; Chaturvedi, R.R.; Manshaei, R.; Costain, G.; Heung, T.; Curtis, M.; Hosseini, S.M.; Liston, E.; Lowther, C.; et al. Haploinsufficiency of vascular endothelial growth factor related signaling genes is associated with tetralogy of Fallot. Genet. Med. 2018, 21, 1001-1007. [CrossRef]

20. Zhao, W.; Wang, J.; Shen, J.; Sun, K.; Zhu, J.; Yu, T.; Ji, W.; Chen, Y.; Fu, Q.; Li, F. Mutations in VEGFA are associated with congenital left ventricular outflow tract obstruction. Biochem. Biophys. Res. Commun. 2010, 396, 483-488. [CrossRef]

21. Beghetti, M.; Rudzinski, A.; Zhang, M. Efficacy and safety of oral sildenafil in children with Down syndrome and pulmonary hypertension. BMC Cardiovasc. Disord. 2017, 17, 177. [CrossRef]

22. Zhu, N.; Welch, C.L.; Wang, J.; Allen, P.M.; Gonzaga-Jauregui, C.; Ma, L.; King, A.K.; Krishnan, U.; Rosenzweig, E.B.; Ivy, D.D.; et al. Rare variants in SOX17 are associated with pulmonary arterial hypertension with congenital heart disease. Genome Med. 2018, 10, 56. [CrossRef] [PubMed]

23. Byers, H.M.; Dagle, J.M.; Klein, J.M.; Ryckman, K.K.; McDonald, E.L.; Murray, J.C.; Borowski, K.S. Variations in CRHR1 are associated with persistent pulmonary hypertension of the newborn. Pediatr. Res. 2012, 71, 162-167. [CrossRef] [PubMed]

24. Arora, R.; Metzger, R.J.; Papaioannou, V.E. Multiple roles and interactions of Tbx4 and Tbx5 in development of the respiratory system. PLoS Genet. 2012, 8, e1002866. [CrossRef]

25. Kanai-Azuma, M.; Kanai, Y.; Gad, J.M.; Tajima, Y.; Taya, C.; Kurohmaru, M.; Sanai, Y.; Yonekawa, H.; Yazaki, K.; Tam, P.P.; et al. Depletion of definitive gut endoderm in Sox17-null mutant mice. Development 2002, 129, 2367-2379.

26. Lilly, A.J.; Lacaud, G.; Kouskoff, V. SOXF transcription factors in cardiovascular development. Semin. Cell Dev. Biol. 2017, 63, 50-57. [CrossRef]

27. Sheeba, C.J.; Logan, M.P. The roles of T-box genes in vertebrate limb development. Curr. Top Dev. Biol. 2017, 122, 355-381. [PubMed]

28. Ballif, B.C.; Theisen, A.; Rosenfeld, J.A.; Traylor, R.N.; Gastier-Foster, J.; Thrush, D.L.; Astbury, C.; Bartholomew, D.; McBride, K.L.; Pyatt, R.E.; et al. Identification of a recurrent microdeletion at 17q23.1q23.2 flanked by segmental duplications associated with heart defects and limb abnormalities. Am. J. Hum. Genet. 2010, 86, 454-461. [CrossRef]

29. Nimmakayalu, M.; Sheffield, V.C.; Solomon, D.H.; Patil, S.R.; Shchelochkov, O.A.; Major, H.; Smith, R.J. Microdeletion of 17q22q23.2 encompassing TBX2 and TBX4 in a patient with congenital microcephaly, thyroid duct cyst, sensorineural hearing loss, and pulmonary hypertension. Am. J. Med. Genet. Part A 2011, 155A, 418-423. [CrossRef]

30. Kerstjens-Frederikse, W.S.; Bongers, E.M.H.F.; Roofthooft, M.T.R.; Leter, E.M.; Douwes, J.M.; Van Dijk, A.; Vonk-Noordegraaf, A.; Dijk-Bos, K.K.; Hoefsloot, L.H.; Hoendermis, E.S.; et al. TBX4mutations (small patella syndrome) are associated with childhood-onset pulmonary arterial hypertension. J. Med. Genet. 2013, 50, 500-506. [CrossRef]

31. Levy, M.; Eyries, M.; Szezepanski, I.; Ladouceur, M.; Nadaud, S.; Bonnet, D.; Soubrier, F. Genetic analyses in a cohort of children with pulmonary hypertension. Eur. Respir. J. 2016, 48, 1118-1126. [CrossRef] [PubMed]

32. Navas, P.; Tenorio, J.; Quezada, C.A.; Barrios, E.; Gordo, G.; Arias, P.; Messeguer, M.L.; Santos-Lozano, A.; Doza, J.P.; Lapunzina, P.; et al. Molecular analysis of BMPR2, TBX4, and KCNK3 and genotype-phenotype correlations in Spanish patients and families with idiopathic and hereditary pulmonary arterial hypertension. Rev. Esp. Cardiol. 2016, 69, 1011-1019. [CrossRef] [PubMed]

33. Homsy, J.; Zaidi, S.; Shen, Y.; Ware, J.S.; Samocha, K.E.; Karczewski, K.J.; DePalma, S.R.; Mckean, D.; Wakimoto, H.; Gorham, J.; et al. De novo mutations in congenital heart disease with neurodevelopmental and other congenital anomalies. Science 2015, 350, 1262-1266. [CrossRef] [PubMed]

34. Galambos, C.; Mullen, M.P.; Shieh, J.T.; Schwerk, N.; Kielt, M.J.; Ullmann, N.; Boldrini, R.; Stucin-Gantar, I.; Haass, C.; Bansal, M.; et al. Phenotype characterisation of TBX4 mutation and deletion carriers with neonatal and pediatric pulmonary hypertension. Eur. Respir. J. 2019, 54, 1801965. [CrossRef] [PubMed]

35. Thoré, P.; Girerd, B.; Jaïs, X.; Savale, L.; Ghigna, M.R.; Eyries, M.; Levy, M.; Ovaert, C.; Servettaz, A.; Guillaumot, A.; et al. Phenotype and outcome of pulmonary arterial hypertension patients carrying a TBX4 mutation. Eur. Respir. J. 2020, 55, 1902340. [CrossRef] 
36. Austin, E.D.; Elliott, C.G. TBX4 syndrome: A systemic disease highlighted by pulmonary arterial hypertension in its most severe form. Eur. Respir. J. 2020, 55, 2000585. [CrossRef]

37. Corada, M.; Orsenigo, F.; Morini, M.F.; Pitulescu, M.E.; Bhat, G.; Nyqvist, D.; Breviario, F.; Conti, V.; Briot, A.; Iruela-Arispe, M.L.; et al. Sox17 is indispensable for acquisition and maintenance of arterial identity. Nat. Commun. 2013, 4, 2609. [CrossRef]

38. Sakamoto, Y.; Hara, K.; Kanai-Azuma, M.; Matsui, T.; Miura, Y.; Tsunekawa, N.; Kurohmaru, M.; Saijoh, Y.; Koopman, P.; Kanai, Y. Redundant roles of Sox17 and Sox18 in early cardiovascular development of mouse embryos. Biochem. Biophys. Res. Commun. 2007, 360, 539-544. [CrossRef] [PubMed]

39. Lange, A.W.; Haitchi, H.M.; LeCras, T.D.; Sridharan, A.; Xu, Y.; Wert, S.E.; James, J.; Udell, N.; Thurner, P.J.; Whitsett, J.A. Sox17 is required for normal pulmonary vascular morphogenesis. Dev. Biol. 2014, 387, 109-120. [CrossRef]

40. Liu, M.; Zhang, L.; Marsboom, G.; Jambusaria, A.; Xiong, S.; Toth, P.T.; Benevolenskaya, E.V.; Rehman, J.; Malik, A.B. Sox17 is required for endothelial regeneration following inflammation-induced vascular injury. Nat. Commun. 2019, 10, 2126. [CrossRef]

41. Gräf, S.; Haimel, M.; Bleda, M.; Hadinnapola, C.; Southgate, L.; Li, W.; Hodgson, J.; Liu, B.; Salmon, R.M.; Southwood, M.; et al. Identification of rare sequence variation underlying heritable pulmonary arterial hypertension. Nat. Commun. 2018, 9, 1416. [CrossRef] [PubMed]

42. Hiraide, T.; Kataoka, M.; Suzuki, H.; Aimi, Y.; Chiba, T.; Kanekura, K.; Satoh, T.; Fukuda, K.; Gamou, S.; Kosaki, K. SOX17 Mutations in Japanese patients with pulmonary arterial hypertension. Am. J. Respir. Crit. Care Med. 2018, 198, 1231-1233. [CrossRef]

43. Liu, X.; Luo, M.; Xie, W.; Wells, J.M.; Goodheart, M.J.; Engelhardt, J.F. Sox17 modulates Wnt3A/ $\beta$-catenin-mediated transcriptional activation of the Lef-1 promoter. Am. J. Physiol. Lung Cell. Mol. Physiol. 2010, 299, L694-L710. [CrossRef]

44. Banerjee, A.; Ray, S. Structural insight, mutation and interactions in human $\beta$-catenin and SOX17 protein: A molecular-level outlook for organogenesis. Gene 2017, 610, 118-126. [CrossRef]

45. Zhang, H.S.; Liu, Q.; Piao, C.M.; Zhu, Y.; Li, Q.Q.; Du, J.; Gu, H. Genotypes and phenotypes of Chinese pediatric patients with idiopathic and heritable pulmonary arterial hypertension-A single-center study. Can. J. Cardiol. 2019, 35, 1851-1856. [CrossRef]

46. Haarman, M.G.; Kerstjens-Frederikse, W.S.; Vissia-Kazemier, T.R.; Breeman, K.T.; Timens, W.; Vos, Y.J.; Roofthooft, M.T.; Hillege, H.L.; Berger, R.M. The genetic epidemiology of pediatric pulmonary arterial hypertension. J. Pediatr. 2020, 225, 65-73. [CrossRef]

47. Wang, G.; Fan, R.; Ji, R.; Zou, W.; Penny, D.J.; Varghese, N.P.; Fan, Y. Novel homozygous BMP9 nonsense mutation causes pulmonary arterial hypertension: A case report. BMC Pulm. Med. 2016, 16, 17. [CrossRef]

48. Qi, H.; Yu, L.; Zhou, X.; Wynn, J.; Zhao, H.; Guo, Y.; Zhu, N.; Kitaygorodsky, A.; Hernan, R.; Aspelund, G.; et al. De novo variants in congenital diaphragmatic hernia identify MYRF as a new syndrome and reveal genetic overlaps with other developmental disorders. PLoS Genet. 2018, 14, e1007822. [CrossRef] [PubMed]

49. Jin, S.C.; Homsy, J.; Zaidi, S.; Lu, Q.; Morton, S.; DePalma, S.R.; Zeng, X.; Qi, H.; Chang, W.; Sierant, M.C.; et al. Contribution of rare inherited and de novo variants in 2871 congenital heart disease probands. Nat. Genet. 2017, 49, 1593-1601. [CrossRef]

50. Epi, K.C.; Allen, A.S.; Berkovic, S.F.; Cossette, P.; Delanty, N.; Dlugos, D.; Eichler, E.E.; Epstein, M.P.; Glauser, T.; Goldstein, D.B.; et al. De novo mutations in epileptic encephalopathies. Nature 2013, 501, 217-221.

51. Veltman, J.A.; Brunner, H.G. De novo mutations in human genetic disease. Nat. Rev. Genet. 2012, 13, 565-575. [CrossRef]

52. Page, D.J.; Miossec, M.J.; Williams, S.G.; Monaghan, R.M.; Fotiou, E.; Cordell, H.J.; Sutcliffe, L.; Topf, A.; Bourgey, M.; Bourque, G.; et al. Whole exome sequencing reveals the major genetic contributors to nonsyndromic tetralogy of fallot. Circ. Res. 2019, 124, 553-563. [CrossRef]

53. Tartaglia, M.; Martinelli, S.; Stella, L.; Bocchinfuso, G.; Flex, E.; Cordeddu, V.; Zampino, G.; Van Der Burgt, I.; Palleschi, A.; Petrucci, T.C.; et al. Diversity and functional consequences of germline and somatic PTPN11 mutations in human disease. Am. J. Hum. Genet. 2006, 78, 279-290. [CrossRef]

54. Hopper, R.K.; Feinstein, J.A.; Manning, M.A.; Benitz, W.; Hudgins, L. Neonatal pulmonary arterial hypertension and Noonan syndrome: Two fatal cases with a specific RAF1 mutation. Am. J. Med. Genet. Part. A 2015, 167A, 882-885. [CrossRef] [PubMed] 
55. Tinker, A.; Uren, N.; Schofield, J. Severe pulmonary hypertension in Ullrich-Noonan syndrome. Br. Heart J. 1989, 62, 74-77. [CrossRef] [PubMed]

56. Troyanovsky, B.; Levchenko, T.; Mansson, G.; Matvijenko, O.; Holmgren, L. Angiomotin: An angiostatin binding protein that regulates endothelial cell migration and tube formation. J. Cell Biol. 2001, 152, 1247-1254. [CrossRef] [PubMed]

57. Holmgren, L.; Ambrosino, E.; Birot, O.; Tullus, C.; Veitonmaki, N.; Levchenko, T.; Carlson, L.M.; Musiani, P.; Iezzi, M.; Curcio, C.; et al. A DNA vaccine targeting angiomotin inhibits angiogenesis and suppresses tumor growth. Proc. Natl. Acad. Sci. USA 2006, 103, 9208-9213. [CrossRef]

58. Zheng, Y.; Vertuani, S.; Nyström, S.; Audebert, S.; Meijer, I.; Tegnebratt, T.; Borg, J.P.; Uhlén, P.; Majumdar, A.; Holmgren, L. Angiomotin-like protein 1 controls endothelial polarity and junction stability during sprouting angiogenesis. Circ. Res. 2009, 105, 260-270. [CrossRef]

59. Mohamed, B.A.; Barakat, A.Z.; Held, T.; Elkenani, M.; Mühlfeld, C.; Männer, J.; Adham, I.M. Respiratory distress and early neonatal lethality in Hspa41/Hspa4 double-mutant mice. Am. J. Respir. Cell Mol. Biol. 2014, 50, 817-824. [CrossRef]

60. Ungvari, Z.; Bagi, Z.; Feher, A.; Recchia, F.A.; Sonntag, W.E.; Pearson, K.; De Cabo, R.; Csiszar, A. Resveratrol confers endothelial protection via activation of the antioxidant transcription factor Nrf2. Am. J. Physiol. Heart Circ. Physiol. 2010, 299, H18-H24. [CrossRef] [PubMed]

61. Wei, Y.; Gong, J.; Thimmulappa, R.K.; Kosmider, B.; Biswal, S.; Duh, E.J. Nrf2 acts cell-autonomously in endothelium to regulate tip cell formation and vascular branching. Proc. Natl. Acad. Sci. USA 2013, 110, E3910-E3918. [CrossRef]

62. Liu, Q.; Gao, Y.; Ci, X. Role of Nrf2 and its activators in respiratory diseases. Oxid. Med. Cell. Longev. 2019, 2019, 7090534. [CrossRef]

63. Samocha, K.E.; Robinson, E.B.; Sanders, S.J.; Stevens, C.; Sabo, A.; McGrath, L.M.; Kosmicki, J.A.; Rehnström, K.; Mallick, S.; Kirby, A.; et al. A framework for the interpretation of de novo mutation in human disease. Nat. Genet. 2014, 46, 944-950. [CrossRef]

64. Chida, A.; Shintani, M.; Yagi, H.; Fujiwara, M.; Kojima, Y.; Sato, H.; Imamura, S.; Yokozawa, M.; Onodera, N.; Horigome, H.; et al. Outcomes of childhood pulmonary arterial hypertension in BMPR2 and ALK1 mutation carriers. Am. J. Cardiol. 2012, 110, 586-593. [CrossRef]

65. Wang, X.J.; Lian, T.Y.; Jiang, X.; Liu, S.F.; Li, S.Q.; Jiang, R.; Wu, W.H.; Ye, J.; Cheng, C.Y.; Du, Y.; et al. Germline BMP9 mutation causes idiopathic pulmonary arterial hypertension. Eur. Respir. J. 2019, 53, 1801609. [CrossRef]

66. Karczewski, K.J.; Francioli, L.C.; Tiao, G.; Cummings, B.B.; Alföldi, J.; Wang, Q.; Collins, R.L.; Laricchia, K.M.; Ganna, A.; Birnbaum, D.P.; et al. The mutational constraint spectrum quantified from variation in 141,456 humans. Nat. Cell Biol. 2020, 581, 434-443. [CrossRef]

67. Hemnes, A.R. Using omics to understand and treat pulmonary vascular disease. Front. Med. 2018, 5, 157. [CrossRef]

68. Harbaum, L.; Rhodes, C.J.; Otero-Núñez, P.; Wharton, J.; Wilkins, M.R. The application of 'omics' to pulmonary arterial hypertension. Br. J. Pharmacol. 2020. [CrossRef] [PubMed]

69. West, J.; Cogan, J.; Geraci, M.W.; Robinson, L.; Newman, J.H.; Phillips, J.A.; Lane, K.B.; Meyrick, B.; Loyd, J.E. Gene expression in BMPR2 mutation carriers with and without evidence of Pulmonary Arterial Hypertension suggests pathways relevant to disease penetrance. BMC Med. Genom. 2008, 1, 45. [CrossRef] [PubMed]

70. Prosseda, S.D.; Tian, X.; Kuramoto, K.; Boehm, M.; Sudheendra, D.; Miyagawa, K.; Zhang, F.; Solow-Cordero, D.; Saldivar, J.C.; Austin, E.D.; et al. FHIT, a novel modifier gene in pulmonary arterial hypertension. Am. J. Respir. Crit. Care Med. 2019, 199, 83-98. [CrossRef]

71. Rhodes, C.J.; Ghataorhe, P.; Wharton, J.; Rue-Albrecht, K.C.; Hadinnapola, C.; Watson, G.; Bleda, M.; Haimel, M.; Coghlan, G.; Corris, P.A.; et al. Plasma metabolomics implicates modified transfer RNAs and altered bioenergetics in the outcomes of pulmonary arterial hypertension. Circulation 2017, 135, 460-475. [CrossRef]

72. Stearman, R.S.; Bui, Q.M.; Speyer, G.; Handen, A.; Cornelius, A.R.; Graham, B.B.; Kim, S.; Mickler, E.A.; Tuder, R.M.; Chan, S.Y.; et al. Systems analysis of the human pulmonary arterial hypertension lung transcriptome. Am. J. Respir. Cell Mol. Biol. 2019, 60, 637-649. [CrossRef] 
73. Hemnes, A.R.; Trammell, A.W.; Archer, S.L.; Rich, S.; Yu, C.; Nian, H.; Penner, N.; Funke, M.; Wheeler, L.; Robbins, I.M.; et al. Peripheral blood signature of vasodilator-responsive pulmonary arterial hypertension. Circulation 2014, 131, 401-409. [CrossRef]

74. Abman, S.H.; Raj, U. Towards improving the care of children with pulmonary hypertension: The rationale for developing a pediatric pulmonary hypertension network. Prog. Pediatr. Cardiol. 2009, 27, 3-6. [CrossRef] [PubMed]

75. Abman, S.H.; Kinsella, J.P.; Rosenzweig, E.B.; Krishnan, U.; Kulik, T.; Mullen, M.; Wessel, D.L.; Steinhorn, R.; Adatia, I.; Hanna, B.D.; et al. Implications of the U.S. Food and drug administration warning against the use of sildenafil for the treatment of pediatric pulmonary hypertension. Am. J. Respir. Crit. Care Med. 2013, 187, 572-575. [CrossRef] [PubMed]

76. Krishnan, U.; Feinstein, J.A.; Adatia, I.; Austin, E.D.; Mullen, M.P.; Hopper, R.K.; Hanna, B.D.; Romer, L.; Keller, R.L.; Fineman, J.; et al. Evaluation and management of pulmonary hypertension in children with bronchopulmonary dysplasia. J. Pediatr. 2017, 188, 24-34.E1. [CrossRef] [PubMed]

77. Kinsella, J.P.; Steinhorn, R.; Mullen, M.P.; Hopper, R.K.; Keller, R.L.; Ivy, D.D.; Austin, E.D.; Krishnan, U.; Rosenzweig, E.B.; Fineman, J.R.; et al. The left ventricle in congenital diaphragmatic hernia: Implications for the management of pulmonary hypertension. J. Pediatr. 2018, 197, 17-22. [CrossRef]

78. Levy, P.T.; Jain, A.; Nawaytou, H.; Teitel, D.; Keller, R.; Fineman, J.; Steinhorn, R.; Abman, S.H.; McNamara, P.J. Risk assessment and monitoring of chronic pulmonary hypertension in premature infants. J. Pediatr. 2020, 217, 199-209.e4. [CrossRef]

79. Hemnes, A.R.; Beck, G.J.; Newman, J.H.; Abidov, A.; Aldred, M.A.; Barnard, J.; Berman, R.E.; Borlaug, B.A.; Chung, W.K.; Comhair, S.A.A.; et al. PVDOMICS: A multi-center study to improve understanding of pulmonary vascular disease through phenomics. Circ. Res. 2017, 121, 1136-1139. [CrossRef]

80. Simonneau, G.; Montani, D.; Celermajer, D.S.; Denton, C.P.; Gatzoulis, M.A.; Krowka, M.; Williams, P.G.; Souza, R. Haemodynamic definitions and updated clinical classification of pulmonary hypertension. Eur. Respir. J. 2019, 53, 1801913. [CrossRef]

81. Del Cerro, M.J.; Abman, S.; Diaz, G.; Freudenthal, A.H.; Freudenthal, F.; Harikrishnan, S.; Haworth, S.G.; Ivy, D.; Lopes, A.A.; Raj, J.U.; et al. A consensus approach to the classification of pediatric pulmonary hypertensive vascular disease: Report from the PVRI pediatric taskforce, Panama 2011. Pulm. Circ. 2011, 1, 286-298. [CrossRef] [PubMed]

82. Feliciano, P.; Daniels, A.M.; Snyder, L.G.; Beaumont, A.; Camba, A.; Esler, A.; Gulsrud, A.; Mason, A.; Gutierrez, A.; Nicholson, A.; et al. SPARK: A US cohort of 50,000 families to accelerate autism research. Neuron 2018, 97, 488-493. [CrossRef] [PubMed]

83. Feliciano, P.; The SPARK Consortium; Zhou, X.; Astrovskaya, I.; Turner, T.N.; Wang, T.; Brueggeman, L.; Barnard, R.; Hsieh, A.; Snyder, L.G.; et al. Exome sequencing of 457 autism families recruited online provides evidence for autism risk genes. NPJ Genom. Med. 2019, 4, 19. [CrossRef]

84. Chaisson, N.F.; Dodson, M.W.; Elliott, C.G. Pulmonary capillary hemangiomatosis and pulmonary veno-occlusive disease. Clin. Chest Med. 2016, 37, 523-534. [CrossRef]

85. Plauchu, H.; De Chadarévian, J.P.; Bideau, A.; Robert, J.-M. Age-related clinical profile of hereditary hemorrhagic telangiectasia in an epidemiologically recruited population. Am. J. Med. Genet. 1989, 32, 291-297. [CrossRef]

Publisher's Note: MDPI stays neutral with regard to jurisdictional claims in published maps and institutional affiliations.

(C) 2020 by the authors. Licensee MDPI, Basel, Switzerland. This article is an open access article distributed under the terms and conditions of the Creative Commons Attribution (CC BY) license (http://creativecommons.org/licenses/by/4.0/). 